Abstracta Iranica Abstracta Iranica

Revue bibliographique pour le domaine irano-aryen

Volume 27 | 2006

Comptes rendus des publications de 2004

\title{
" An attempt to systematize the gates in the Urartian fortresses ». Iranica Antiqua, vol. XXXIX, (2004), pp. 169-190, IV fig.
}

\section{Rémy Boucharlat}

\section{(2) OpenEdition}

1 Journals

\section{Édition électronique}

URL : http://journals.openedition.org/abstractairanica/5718

DOI : 10.4000/abstractairanica.5718

ISSN : 1961-960X

Éditeur :

CNRS (UMR 7528 Mondes iraniens et indiens), Éditions de l'IFRI

\section{Édition imprimée}

Date de publication : 15 mai 2006

ISSN : 0240-8910

Référence électronique

Rémy Boucharlat, « "An attempt to systematize the gates in the Urartian fortresses ». Iranica Antiqua, vol. XXXIX, (2004), pp. 169-190, IV fig. », Abstracta Iranica [En ligne], Volume 27 | 2006, document 80, mis en ligne le 02 janvier 2007, consulté le 25 septembre 2020. URL : http://journals.openedition.org/ abstractairanica/5718; DOI : https://doi.org/10.4000/abstractairanica.5718

Ce document a été généré automatiquement le 25 septembre 2020.

Tous droits réservés 


\title{
« An attempt to systematize the gates in the Urartian fortresses $»$. Iranica Antiqua, vol. XXXIX, (2004), pp. 169-190, IV fig.
}

\author{
Rémy Boucharlat
}

L'architecture défensive en pierre de l'Urartu ( $\left(9^{\mathrm{e}}-7^{\mathrm{e}} \mathrm{s}\right.$. av. J.-C.) est non seulement remarquable par sa qualité et sa parfaite intégration dans la topographie accidentée des régions montagneuses de l'Azerbaijan iranien, l'Anatolie orientale et l'Arménie, mais aussi par la possibilité de l'observer aujourd'hui sans fouille, du fait de sa bonne conservation. À la suite d'autres études (Abs. Ir. 26, c.r. n59), l'A. s'intéresse ici aux caractéristiques des portes monumentales et défensives de ces forteresses qu'il ordonne en un grand tableau, accompagné de quelques plans. L'A. suit l'opinion commune et raisonnable selon laquelle l'architecture défensive urartéenne a pour objectif premier la défense du pays contre l'ennemi extérieur, au premier rang desquels se trouvent les Assyriens. On ne s'interroge guère sur la fonction de contrôle des populations locales de cet étonnant réseau de défenses.

INDEX

Thèmes : 3.2.1. Elam

nompropre Azerbaijan 
AUTEURS

RÉMY BOUCHARLAT

IFRI-CNRS - Téhéran-Lyon 